\title{
Synthesis of zinc hydroxide nitrate complex by a sol-gel method for use as foliar fertilizers - a scale up approach
}

- Le Tu Chau

- Ngo Manh Thang

Faculty of Chemical Engineering, Ho Chi Minh city University of Technology, VNU-HCM.

(Manuscript Received on July, 2016, Manuscript Revised on September, 2016)

\section{ABSTRACT}

Zinc hydroxide nitrate complex is a new class of materials with outstanding characteristics promising its application as foliar nano-fertilizers. In this study, nano crystalline zinc hydroxide nitrate powder was synthesized by a sol - gel method using $\mathrm{NaOH}$ and $\mathrm{Zn}\left(\mathrm{NO}_{3}\right)_{2} .6 \mathrm{H}_{2} \mathrm{O}$ as precursors, yielding several grams products per batch. The products were characterized by XRD, FTIR, SEM and

Keywords: Foliar fertilizer, nano-fertilizer, scale-up procedure, Zinc hydroxide nitrate, sol-gel method.

\section{INTRODUCTION}

Folia fertilizers have been applied in increasing extents and become indispensable to high-tech agriculture. Recently, zinc hydroxide nitrate $\mathrm{Zn}_{5}(\mathrm{OH})_{8}\left(\mathrm{NO}_{3}\right)_{2} \cdot 2 \mathrm{H}_{2} \mathrm{O}$ had been reported as a potential long-term zinc supplying foliar fertilizer owing to its appropriate characteristics, e.g. stable nano sized crystals with sheet-like morphology, positively charged surface and moderate solubility in water $[\mathbf{1 , 2}]$. Moreover, copper could be involved to provide foliar fertilizers functioning as dual micronutriens to foliars [3]. In fact, $\mathrm{Zn}_{5}(\mathrm{OH})_{8}\left(\mathrm{NO}_{3}\right)_{2} \cdot 2 \mathrm{H}_{2} \mathrm{O}$ has been known for a long time as a representantive
$B E T$, indicating the initial molar ratio $\mathrm{NaOH}$ : $\mathrm{Zn}\left(\mathrm{NO}_{3}\right)_{2} \cdot 6 \mathrm{H}_{2} \mathrm{O}=1.6$ and reaction time 1 hour as suitable. Under the indicated conditions, the particle size of products is in the range $50 \div 100$ $\mathrm{nm}$. The characteristics of products demonstrate their potential application as foliar nanofertilizer and the synthesis procedure might be further upgrading to production extents. of layered hydroxide salts. Its preparation was newly patented concerning application as foliar fertilizer [4]. However, only the procedure in laboratory scale was described and boundary parameters suggested, e.g. 1 hour reaction time, concentration $0.2 \mathrm{M} \mathrm{NaOH}$, and initial molar ratio $\mathrm{OH}^{-} / \mathrm{Zn}^{2+}=1.6$ were suggested from the investigated ranges 1 hour $\div 24$ hour, $0.2 \mathrm{M} \div$ $1.6 \mathrm{M} \mathrm{NaOH}$, and $0.5 \div 1.6$, respectively [1]. In order to follow this procedure, additional investigation beyond the reported ranges, e.g. stirring time shorter than 1 hour, initial $\mathrm{OH}^{-} /$ $\mathrm{Zn}^{2+}>1.6$ should be conducted. Moreover, the synthesis of $\mathrm{Zn}_{5}(\mathrm{OH})_{8}\left(\mathrm{NO}_{3}\right)_{2} \cdot 2 \mathrm{H}_{2} \mathrm{O}$ should be

\section{Trang 138}


scaled up towards its possible application as foliar fertilizer.

This paper describes our preliminary results of such attempts to scale up. First, both the concentrations of precursors' solutions were increased to $0.6 \mathrm{M}$ and the initial molar ratio $\mathrm{OH}^{-} / \mathrm{Zn}^{2+}$ as well as aging time adjusted. Then both their volumes were increased accordingly 5- to 20-fold, resulting in its production of about $70 \mathrm{~g}$ of $\mathrm{Zn}_{5}(\mathrm{OH})_{8}\left(\mathrm{NO}_{3}\right)_{2} \cdot 2 \mathrm{H}_{2} \mathrm{O}$ per batch.

\section{EXPERIMENTAL}

$\mathrm{Zn}\left(\mathrm{NO}_{3}\right)_{2} \cdot 6 \mathrm{H}_{2} \mathrm{O}$ (reagent grade $98 \%$ ) and $\mathrm{NaOH}$ (reagent grade 99\%) from China were used without further purification. Ultrapure water was obtained from a reverse osmosis system. Two stock solutions $0.6 \mathrm{M} \mathrm{Zn}\left(\mathrm{NO}_{3}\right)_{2}$ and $0.6 \mathrm{M} \mathrm{NaOH}$ were prepared dissolution appropriate amounts of chemicals in water and stored at ambient conditions.

Fig.1 shows the procedure scheme of a typical laboratory scale experiment: $80 \mathrm{ml} 0.6 \mathrm{M}$ $\mathrm{NaOH}$ were gradually added to $50 \mathrm{ml} 0.6 \mathrm{M}$ $\mathrm{Zn}\left(\mathrm{NO}_{3}\right)_{2}$ under vigorous stirring at room temperature $\left(28^{\circ} \mathrm{C} \pm 2^{\circ} \mathrm{C}\right)$ for 1 hour. The resulting white precipitates were filtered, washed several times with ultrapure water, then dried at $50^{\circ} \mathrm{C}$ for 24 hours. The investigated parameters were initial $\mathrm{OH}-/ \mathrm{Zn}^{2+}$ molar ratio $(0.5,1.0,1.6,2.0$ corresponding to $25 \mathrm{ml}, 50 \mathrm{ml}$, $80 \mathrm{ml}$ and $100 \mathrm{ml} 0.6 \mathrm{M} \mathrm{NaOH}$ vs. $50 \mathrm{ml} 0.6 \mathrm{M}$ $\left.\mathrm{Zn}\left(\mathrm{NO}_{3}\right)_{2}\right)$ and stirring time (15 min., $30 \mathrm{~min}$., 45 min., 1 hour).

Scale - up experiments were conducted using 5-fold and 20-fold volumes of both the stock solutions at the initial $\mathrm{OH}^{-} / \mathrm{Zn}^{2+}$ molar ratio 1.6, i.e. adding $400 \mathrm{ml} 0.6 \mathrm{M} \mathrm{NaOH}$ to 250 $\mathrm{ml} 0.6 \mathrm{M} \mathrm{Zn}\left(\mathrm{NO}_{3}\right)_{2}$ or $1600 \mathrm{ml} 0.6 \mathrm{M} \mathrm{NaOH}$ to $1000 \mathrm{ml} 0.6 \mathrm{M} \mathrm{Zn}\left(\mathrm{NO}_{3}\right)_{2}$, respectively. Instead of magnetic stirrer, a blade mixer at around 180 rpm and room temperature was applied to assure extensive mixing for 1 hour. The filtering, washing and drying steps remained similar as in laboratory scale experiments.

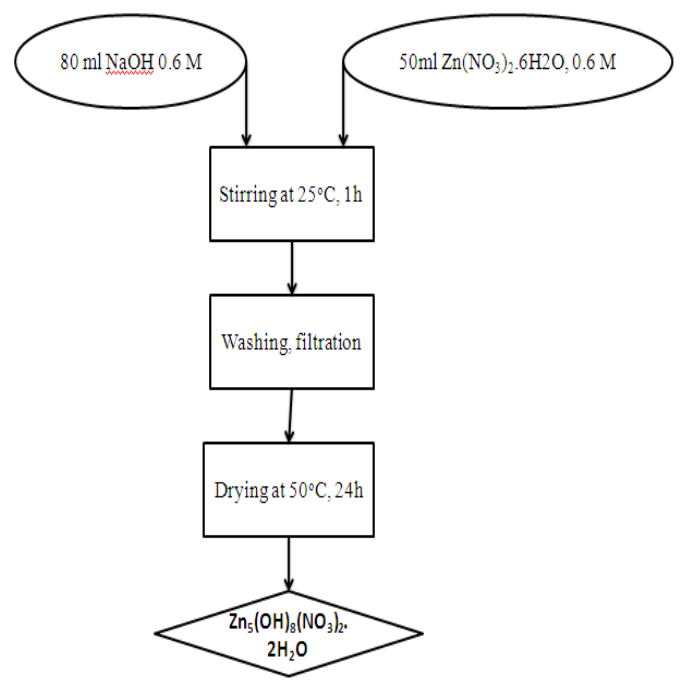

Figure 1. Procedure of the typical laboratory scale experiment

All products were characterized under the same conditions and results compared with each other. The XRD patterns were collected using a D8 Advance Diffractometer (Bruker AXS), Ni MultiFlex $\mathrm{X}$ - ray diffraction and $\mathrm{Cu} \mathrm{K}(\alpha)(\lambda=$ $1.54184 \AA$ ) radiation. The beam voltage and beam current are $40 \mathrm{kV}$ and $40 \mathrm{~mA}$, respectively. A two theta range of $5-70^{\circ}$ with a continous scan rate of $3^{\circ} / \mathrm{min}$ was applied and the phases identified using the Joint Committee on Powder Diffraction Society (JCPDS) database. The Fourier transform infrared (FTIR) spectra of products were obtained using the Bruker Equinox 55 (in the range $4000-400 \mathrm{~cm}^{-1}$ ) equipped with a DTGS detector from FT - IR (Institute of Material Science - Vietnam Academy of Science and Technology). The morphology and particle size of products were 
studied by a S-4800 instrument with an accelerating voltage of $10 \mathrm{kV}$ (Hitachi, Japan). The specific surface areas of products were recorded in a Quantachrome Instrument version 10.0 .

\section{RESULT AND DISCUSSIONS}

\subsection{Scaling-up the initial concentration of precursors}

The synthesis procedure presented in Fig.1 resembles the one described by $\mathrm{Li}$ et al [1], except for higher concentrations of precursors (both $0.6 \mathrm{M}$ instead of $0.2 \mathrm{M}$ ) and slightly higher ambient temperature $\left(28 \pm 2{ }^{0} \mathrm{C}\right.$ instead of $\left.25^{\circ} \mathrm{C}\right)$. $\mathrm{Li}$ et al [1] also tried with concentration 1.6 M NaOH but concluded the smaller one - i.e. $0.2 \mathrm{M}$ - is more suitable, though the concentration of $\mathrm{Zn}\left(\mathrm{NO}_{3}\right)_{2}$ in the former case was not clearly specified. In fact, Newman et al. [5] synthesized the same product dropping $50 \mathrm{ml} 0.75 \mathrm{M} \mathrm{NaOH}$ into $20 \mathrm{ml} 3.5 \mathrm{M}$ $\mathrm{Zn}\left(\mathrm{NO}_{3}\right)_{2}$ at room temperature, followed by an immediate filtration step. They did not recommend initial molar ratios $\mathrm{OH}^{-} / \mathrm{Zn}^{2+}$ higher than 0.5 because $\mathrm{ZnO}$ would appear as impurities in products [5]. However, Li et al [1] did not detect such impurities even with the initial molar ratio $\mathrm{OH}^{-} / \mathrm{Zn}^{2+}=1.6$ using lower concentrations of both precursors $(0.2 \mathrm{M})$. The main reason of this discrepancy is the rather slow kinetics of reaction:

$$
5 \mathrm{Zn}^{2+}+2 \mathrm{NO}_{3}^{-}+8 \mathrm{OH}^{-}=\mathrm{Zn}_{5}(\mathrm{OH})_{8}\left(\mathrm{NO}_{3}\right)_{2}
$$

If some local concentrations of "free" $\mathrm{OH}^{-}$ in the mixture were high enough during the reaction course, they could even attack the freshly formed $\mathrm{Zn}_{5}(\mathrm{OH})_{8}\left(\mathrm{NO}_{3}\right)_{2}$, resulting in its structural changes to $\mathrm{ZnO}$. Therefore, this work just scaled up the initial $\mathrm{NaOH}$ concentration to
0.6 $\mathrm{M}$ and re-checked the effect of initial molar ratio $\mathrm{OH}^{-} / \mathrm{Zn}^{2+}$.

\subsubsection{Adjusting the initial molar ratio $\mathrm{OH}$ - /} $\mathrm{Zn}^{2+}$

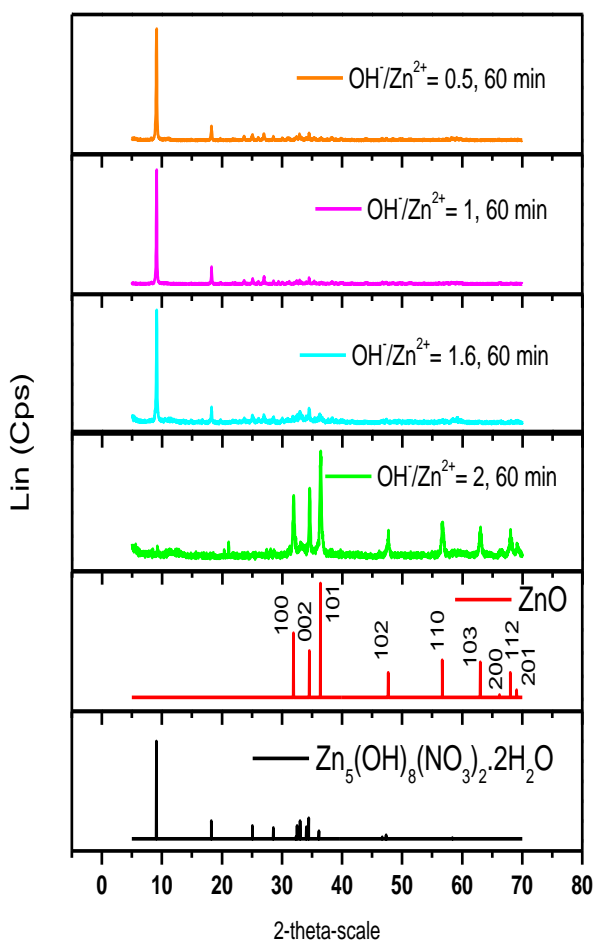

Figure 2. XRD patterns of products with different initial $\mathrm{OH}-/ \mathrm{Zn} 2+$ molar ratios

Fig. 2 shows the XRD patterns of the "as synthesized" products at different initial molar ratios $\mathrm{OH}-/ \mathrm{Zn}^{2+}=0.5,1.0,1.6$ and 2.0, together with the reference data for $\mathrm{ZnO}$ (JCPDS card 36-1451) [6,7] and $\mathrm{Zn}_{5}(\mathrm{OH})_{8}\left(\mathrm{NO}_{3}\right)_{2} \cdot 2 \mathrm{H}_{2} \mathrm{O}$ (JCPDS card 241460) $[1,5,8,9]$. For the initial molar ratios $\mathrm{OH}-/ \mathrm{Zn}^{2+}$ $\leq 1.6$, an intense peak at $2 \theta=9.2^{\circ}$ demonstrating the $\left(\begin{array}{lll}2 & 0 & 0\end{array}\right)$ crystal planes appeared. Another peak at $2 \theta=18.40$ relevant for the (4 00 ) crystal planes is substantially less intense, but still clearly identified. However, further characteristic peaks at $2 \theta=34.6,35.4$, 
46.8, and $47.4^{\circ}$, corresponding to (2 21 ), ( 71 $0)$, ( $\left(\begin{array}{lll}10 & 0 & 0\end{array}\right)$, and $\left(\begin{array}{lll}-7 & 1 & 2\end{array}\right)$ crystal planes, respectively, are insufficiently resolved.

In our experiments, $\mathrm{NaOH}$ and $\mathrm{Zn}\left(\mathrm{NO}_{3}\right)_{2}$ solutions were simply mixed together, $\mathrm{OH}-$ concentrations at the beginning might reach $0.200 \mathrm{M} \div 0.369 \mathrm{M}(\mathrm{OH}-/ \mathrm{Zn} 2+=0.5 \div 1.6)$ compared to about $0.123 \mathrm{M}(\mathrm{OH}-/ \mathrm{Zn} 2+=1.6)$ [1]. Such situations would cause some structural changes of $\mathrm{Zn}_{5}(\mathrm{OH})_{8}\left(\mathrm{NO}_{3}\right)_{2} \cdot 2 \mathrm{H}_{2} \mathrm{O}$, resulting changes in peak intensities. Although this change in peak intensity requires more detailed investigation, all the XRD patterns of synthesized products at initial $\mathrm{OH}^{-} / \mathrm{Zn}^{2+}=0.5 \div$ 1.6 clearly show the typical peaks at $2 \theta \sim 9.80$ and $\quad 18.40$ as the required $\mathrm{Zn}_{5}(\mathrm{OH})_{8}\left(\mathrm{NO}_{3}\right)_{2} \cdot 2 \mathrm{H}_{2} \mathrm{O}$. In order to maximize the material effectiveness, the initial molar ratio $\mathrm{OH}^{-} / \mathrm{Zn}^{2+}=1.6$ was chosen for further study. However, much attention should be paid to the mixing condition to avoid local increase of $\mathrm{pH}$, as a small $\mathrm{pH}$ increase at the initial $\mathrm{OH}^{-} / \mathrm{Zn}^{2+}=$ 2.0 resulted XRD pattern containing only characteristic peaks for $\mathrm{ZnO}$.

\subsubsection{Adjusting the aging time}

As longer aging time than 1 hour is proved to be unsuitable [1], possible effects of shorter aging times were investigated. Fig.2 and Fig.3 compared the XRD paterns and FTIR spectra, respectively, of the as-synthesized products with aging times 15, 30, 45 and 60 minutes. For products with 15 minutes aging time, the obtained XRD pattern already shows characteristic peaks of $\mathrm{Zn}_{5}(\mathrm{OH})_{8}\left(\mathrm{NO}_{3}\right)_{2} \cdot 2 \mathrm{H}_{2} \mathrm{O}$ at $2 \theta=9.20$ and 18.40. For products with longer aging times than 15 minutes, this most intense peak at $2 \theta=9.20$ decreased to about $1 / 2$ while the another characteristic peaks become better resolved. It might be interpreted that structural transformations from ( $(2 \quad 0 \quad 0)$ to another characteristic diffractions of $\mathrm{Zn}_{5}(\mathrm{OH})_{8}\left(\mathrm{NO}_{3}\right)_{2}$ $.2 \mathrm{H}_{2} \mathrm{O}$ occurred. $\mathrm{Li}$ et al [1] also registered a decreasing tendency of the peak at $2 \theta=9.20$ with aging time beyond 1 hour and interpreted it as results of phase transformation from $\mathrm{Zn}_{5}(\mathrm{OH})_{8}\left(\mathrm{NO}_{3}\right)_{2} \cdot 2 \mathrm{H}_{2} \mathrm{O}$ towards $\mathrm{Zn}(\mathrm{OH})_{2}$. It's worth to note that this main peak intensity remained practically unchanged for aging times 30-60 minutes and no characteristic peaks for $\mathrm{Zn}(\mathrm{OH})_{2}$ (compared to JCPDS card 38-0385 $[1,8])$ appeared.

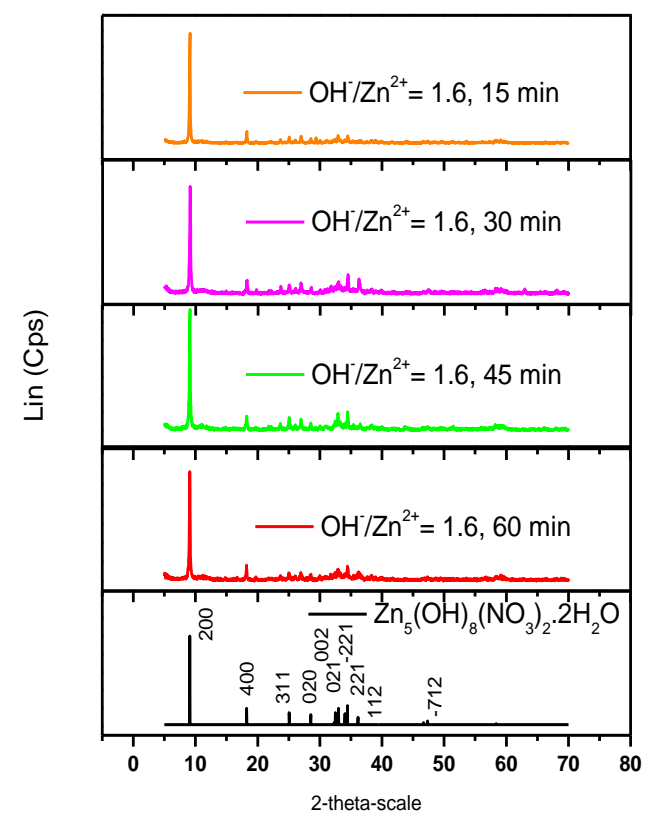

Figure 3. XRD patterns of products with different aging times

The FTIR spectra of all synthesized products with aging times up to 60 minutes resemble each other, with typical peaks of the $\mathrm{Zn}_{5}(\mathrm{OH})_{8}\left(\mathrm{NO}_{3}\right)_{2} \cdot 2 \mathrm{H}_{2} \mathrm{O}$ structure. e.g. the stretching vibrations of the $\mathrm{O}-\mathrm{H}$ bonds resulted a sharp and a strong peak at around $3570 \mathrm{~cm}^{-1}$ and $3500 \mathrm{~cm}^{-1}$, respectively. The presence of 
$\mathrm{H} 2 \mathrm{O}$ molecules in the interlayer space or adsorbed in the surface resulted a shoulder and a peak at around $3300 \mathrm{~cm}^{-1}$ and $1630 \mathrm{~cm}^{-1}$, respectively. Also, vibrations of the nitrate groups are represented by a very strong peak at around $1380 \mathrm{~cm}^{-1}$ and two weak peaks at around $1050 \mathrm{~cm}^{-1}$ and $840 \mathrm{~cm}^{-1}$.

Although the XRD paterns and also the FTIR spectra for products with aging times $30 \div$ 60 minutes do not significantly differ from each other, the aging time of 60 minutes was chosen for further experiments as this process should be scaled up further. It's worth to note that longer aging time is not desirable due to $\mathrm{Zn}_{5}(\mathrm{OH})_{8}\left(\mathrm{NO}_{3}\right)_{2} \cdot 2 \mathrm{H}_{2} \mathrm{O}$ transformation [1]. SEM images shown in Fig.5 reveal sheet-like product entities with thickness from $\sim 20 \mathrm{~nm}$ to $\sim 40 \mathrm{~nm}$, which actually belong to the most required characteristics of our designed products.

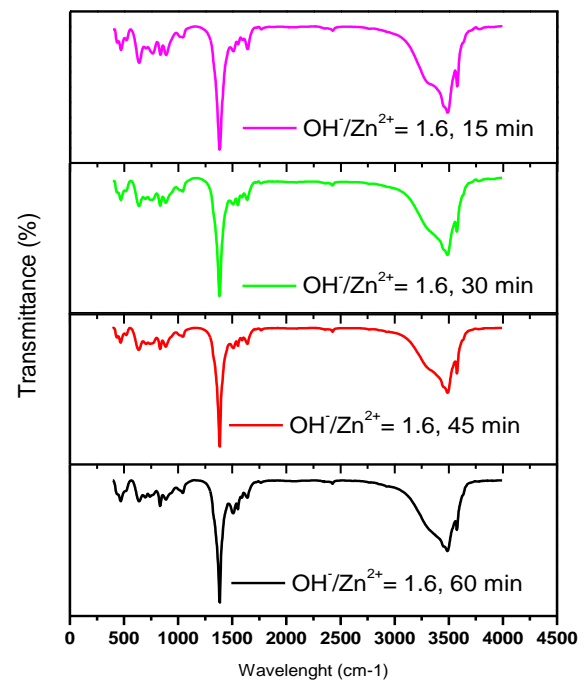

Figure 4. FTIR spectra of products with different aging times

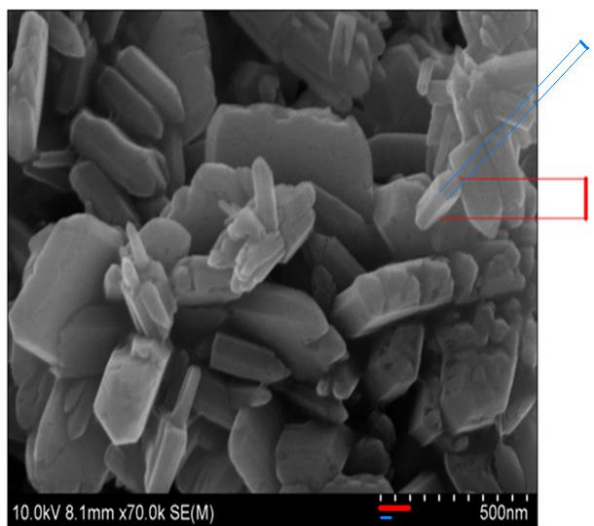

Figure 5. SEM images of products with 60 minutes aging time

\subsection{Scaling-up the volumes of precursors'} solutions

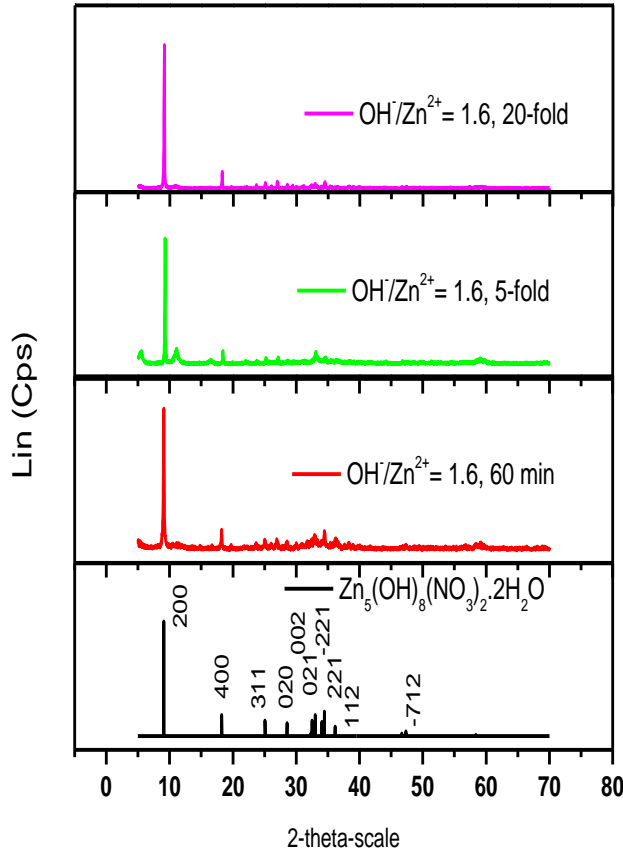

Figure 6. Comparison of XRD patterns of products at volume scaling up experiments

Towards a possible application of products, the precursors' volumes were scaled up 5-fold and 20-fold compared to those described in Fig.1. Much attention had been paid to avoid local overwhelming $\mathrm{pH}$ increase inside the 
reaction mixture, especially the regime to mix the $\mathrm{NaOH}$ and $\mathrm{Zn}\left(\mathrm{NO}_{3}\right)_{2}$ solutions should be individually "tailor-made". Fig.6 e.g. shows that a non-optimized mixing regime caused an additional peak at $2 \theta=100$ in the XRD pattern of products from 5 -fold scaled-up approaches, while such "strange" peaks did not appear in case a good mixing regime was applied in our 20-fold scaled-up approach. The FT-IR spectra in Fig.7 also confirms that characteristic groups of the $\mathrm{Zn}_{5}(\mathrm{OH})_{8}\left(\mathrm{NO}_{3}\right)_{2} \cdot 2 \mathrm{H}_{2} \mathrm{O}$ structure are conserved in the products of our scaled-up approaches.

In addition, Fig. 8 shows that products of our 5-fold and 20-fold volume scaled-up products conserves the desired sheet-like morphology with thickness less than about 50 $\mathrm{nm}$. Comparing with Fig.5, one can see that our volume scaled-up approach did not affect the morphology of products, just increased their mass to about $70 \mathrm{~g}$ per batch.

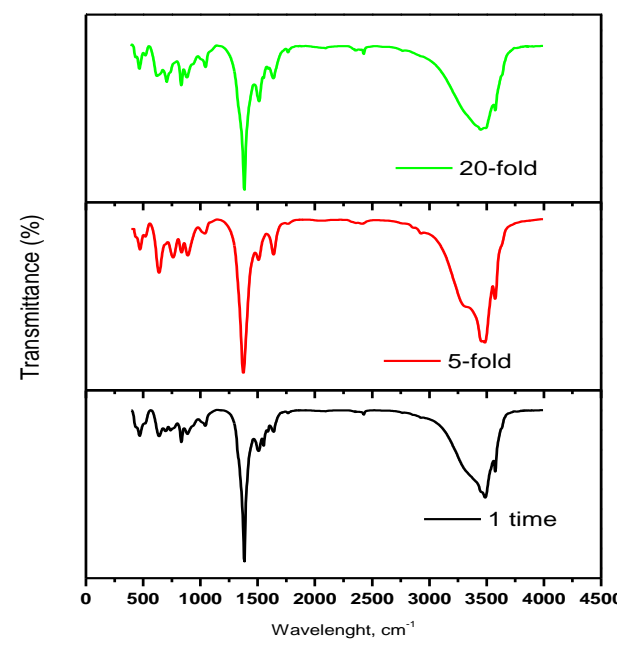

Figure 7. Comparison of FT-IR spectra of products at volume scaling up experiments

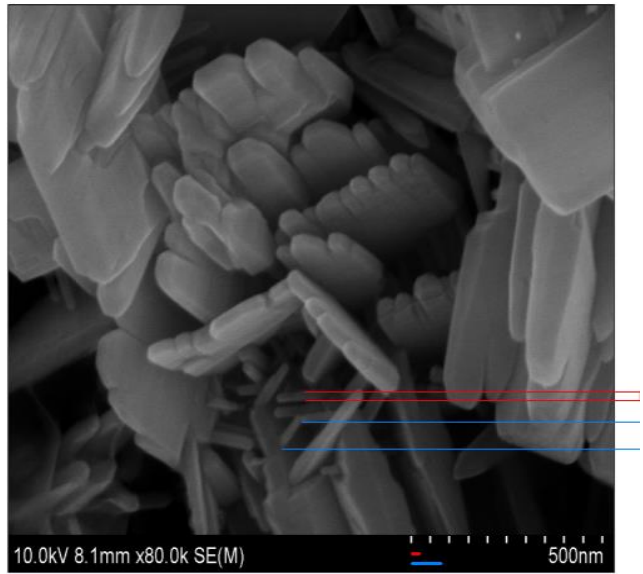

Figure 8. SEM image of products with 5-fold scaledup volumes

\section{CONCLUSIONS}

A laboratory procedure reported in the literature [1] for synthesis of $\mathrm{Zn}_{5}(\mathrm{OH})_{8}\left(\mathrm{NO}_{3}\right)_{2} \cdot 2 \mathrm{H}_{2} \mathrm{O}$ by sol-gel method was verified and scaled-up in both the initial concentrations and precursors' volumes. Under our selected conditions, the resulting products conserve the characteristic XRD patterns, FT-IR spectra and morphology as described in the literature. Comparing to the theoretical value calculated for the cited procedure [1], our product's masses could be increased about 60 fold to $\sim 70 \mathrm{~g}$ per batch. Further scaling-up the precursors' volumes and determination of the product's surface charge are required in order to verify the potential application of products as foliar nano-fertilizer. 


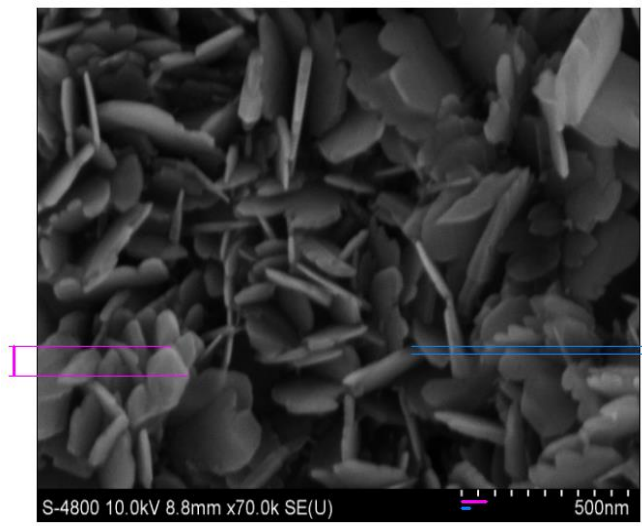

Figure 9. SEM image of products with 20-fold scaled-up volumes
Acknowledgement: This work is financially supported by the HCMUT, School of Graduate Study, under the grant's code TSDH - 2015 KTHH -62 .

\section{Nghiên cứu khả năng nâng cấp qui trình điều chế muối phức kẽm hydroxo-nitrat làm phân nano bón lá bằng phương pháp sol-gel lên qui mô sản xuất}

- Lê Tú Châu

- Ngô Mạnh Thắng

Khoa Kỹ thuật Hóa học, Trường Đại học Bách khoa, ĐHQG-HCM

\section{TÓM TẮT}

Muối phức kẽm hydroxo-nitrat là một dòng vật liệu mới với nhũ̃ng ưu điểm nổi trội hứa hẹn làm phân nano bón lá. Tuy nhiên, thông tin tù tài liệu tham khảo tiếp cận được giới hạn ở mưc độ mg sản phẩm mỗi mẻ điều chế. Trong nghiên cứu này, muối phức kẽm hydroxo nitrat được tổng hợp thành công ở qui mô g sản phẩm mỗi mẻ bằng phuoong pháp sol-gel sử dụng $\mathrm{NaOH}$ và $\mathrm{Zn}\left(\mathrm{NO}_{3}\right)_{2} \cdot 6 \mathrm{H}_{2} \mathrm{O}$ là tác chất. Anh hưởng của tỷ lệ nồng độ tác chất ban đầu và thời gian khuấy trộn đã được khảo sát. Sản phẩm dạng bột được đánh giá bằng các phuoong pháp XRD, FTIR, 
SEM, BET, cho thấy tỷ lệ mol ban đầu $\mathrm{NaOH}$ : $\mathrm{Zn}\left(\mathrm{NO}_{3}\right)_{2} \cdot 6 \mathrm{H}_{2} \mathrm{O}=1.6$ và thời gian khuấy trộn 1 giò̀ là phù hợp. Kích thuoóc hạt của sản phẩm thu được dao động trong vùng $50 \div 10 \mathrm{~nm}$. Kết

Tù khóa: Phân bón lá, phân nano, qui trình nâng cấp, kẽm hydroxo-nitrat, phuơng pháp sol-gel.

\section{REFERENCES}

[1]. P. Li, Z. P. Xu, M. A. Hampton, D. T. Vu, L. Huang, V. Rudolph, A. V. Nguyen. Control Preparation of Zinc Hydroxide Nitrate Nanocrystals and Examination of the Chemical and Structural Stability, J. Phys. Chem. C 116, (2012), 10325-10332.

[2]. T. Vu, L. Huang, A. V. Nguyen, Y. Du, Z. $\mathrm{Xu}$, M. A. Hampton, P. Li, V. Rudolph, Quantitative methods for estimating foliar uptake of zinc from suspension based $\mathrm{Zn}$ chemicals, J. Plant Nutr. Soil Sci. 176, (2013), 764-775.

[3]. P. Li, L. Li, Y. Du, M. A. Hampton, A. V. Nguyen, L. Huang, V. Rudolph, Z. P. Xu, Potential foliar fertilizers with copper and zinc dual micronutrients in nanocrystal suspension, J. Nanopart. Res 16, (2014), 2669.

[4]. L. Huang, A. V. Nguyen, V. Rudolph, G. $\mathrm{Xu}$, Foliar fertilizer, Patent, Appl. Nr. WO 2012/116417 A1,13. (2012).

[5]. S. P. Newman, W. Jones, Comparative study of some layered hydroxide salts quả cho thấy sản phẩm thu được có thể sủ dụng làm phân nano bón lá và qui trình điều chế có thể tiếp tục nâng cấp lên qui mô công nghệ. containing exchangeable interlayer anions, J. Solid State Chem. 148 (1999) 26-40.

[6]. X. R. Qu, D. C. Jia, Synthesis of octahedral $\mathrm{ZnO}$ mesoscale superstructures via thermal decomposing octahedral zinc hydroxide precursors, J. Cryst. Growth 311 (2009) 1223-1228.

[7]. S. Music, D. Dragcevic, S. Popovic, Influence of synthesis route on the formation of $\mathrm{ZnO}$ particles and their morphologies, J. Alloys Compd. 429 (2007) 242-249.

[8]. A. C. T. Cursino, J. E. F. d. C. Gardolinski, F. Wypych, Intercalation of anionic organic ultraviolet ray absorbers into layered zinc hydroxide nitrate, J. Colloid Interface Sci. 347 (2010) 49-55.

[9]. G. S. Machado, G. G. C. Arízaga, F. Wypych, S. J. Nakagaki, Immobilization of anionic metalloporphyrins on zinc hydroxide nitrate and study of an unusual catalytic activity, J. Catal. 247 (2010) 130-141. 